\title{
Prevalence and Associated Factors with Respiratory Problems among Industrial Workers
}

\author{
Pradhan $\mathrm{M}^{1 *}$, Silwal $\mathrm{M}^{2}$ \\ ${ }^{1}$ Staff Nurse, Gandaki Medical College Teaching Hospital, Pokhara, Nepal \\ ${ }^{2}$ Coordinator, College of Nursing Sciences, Gandaki Medical College, Lekhnath, Kaski
}

\section{Keywords \\ Industrial workers, Prevalence, \\ Respiratory problems. \\ Corresponding author \\ *Ms Meenu Pradhan, BSc nursing \\ Staff Nurse, Operation Theatre \\ Gandaki Medical College Teaching \\ Hospital, Pokhara, Nepal \\ Email id: pmeenapradhan@yahoo.com}

\begin{abstract}
Background: In food processing industry, hazardous contaminants are generated. Flour dust has been introduced as one of the effective factors in the prevalence of respiratory disorders among the workers of the flour production factories.
\end{abstract}

Objectives: To assess the prevalence and associated factors with respiratory problems among industrial workers.

Methods: A cross-sectional descriptive study was used for the study. Non- probability purposive sampling technique was applied to choose flour industry and consecutive sampling technique was applied to select the sample from the industry. Hundred fifty respondents were taken as sample and self-administered structured interview questionnaire was used to collect the data.

Results: The study revealed that more than half $103(68.70 \%)$ of the respondents had work-related respiratory problems. The prevalence of cough, phlegm, breathlessness, chest tightness and whistling problems were 100 (66.67\%), 58 (38.67\%), 65 (43.33\%), 9 (6.0\%) and 4 $(2.67 \%)$. Among different demographic variables, association of respiratory problems was found with religion ( $p$ value $=0.015$ ), income per months of respondents ( $p$ value $=0.034$ ) and the information they had about work-related respiratory problems ( $p$ value $=0.000)$.

Conclusions: The study shows that there is higher prevalence of respiratory problems among industrial workers. Also, it shows there is association of respiratory problem with exacerbating factors and health checkup facility in the industry.

\section{INTRODUCTION}

"Occupational safety and health is vital to the dignity of work" - ILO Director-General Juan Somavia.

Industrialization is one of the important foundation stone for the development of a country. For the development of industrialization, it is essential to have enhanced productivity, which can be achievable with safe working environment. In most of the occupational establishments, adequate attention is not paid in making the work and the workplace safe, which may lead to the progress of various work related diseases and accidents ${ }^{1}$.
Nepal is a developing country. It has not been able to manufacture much industrial goods. Manufacturing is still at the developmental stage. Major industries are woolen carpel, garments, textiles, agro-based, leather products, paper and cement. Other products are steel utensils, cigarettes, beverages, sugar, biscuits, noodles etc. There are mostly cottage and medium-scale factories. There are very few large scale industries ${ }^{2}$.

In food processing industry, hazardous contaminants are generated when handling dry, bulk materials or smoke resulting from cooking emissions which can put employers into health risks ${ }^{3}$. As a result, workers are 
at high risk for having asthma and Chronic Obstructive Pulmonary Disease (COPD) ${ }^{4}$. Additionally, flour dust has been introduced as one of the effective factors in the prevalence of respiratory disorders among the workers of the flour production factories 5 .

Respiratory problems can be prevented by identifying harmful substances and measuring the degree of exposure to the work environment, control of exposure including maintenance of ventilation, use of personal protective equipment (PPE) and providing education on occupational disease to develop awareness ${ }^{6}$.

According to the Global Estimates of occupational accidents and fatal work-related diseases in 2014, it is estimated that work-related diseases include seven percent of respiratory diseases ${ }^{7}$. According to WHO Global Plan of Action on Worker's Health (2008 - 2017), the top priority occupational disease of country is occupational respiratory diseases by $59.80 \%$. Respiratory diseases are considered as one of the leading occupational diseases in most countries ${ }^{8}$.

In Nigeria, Calabay, the study which was conducted among flour mill workers revealed that $14.17 \%$ productive cough, $27.06 \%$ unproductive cough, $13.02 \%$ chest pain, $3.15 \%$ dyspnea, $9.16 \%$ sneezing, $25.34 \%$ catarrh and $8.10 \%$ wheezing among test group whereas than control group showed $47.99 \%$ productive cough, $17.45 \%$ unproductive cough, $6 \%$ chest pain, $1.68 \%$ dyspnea, $3.42 \%$ sneezing, $19.62 \%$ catarrh and $3.84 \%$ wheezing. This study concluded that the high incidence of respiratory symptoms in the wheat flour mill workers may not only be attributed to chronic exposure to organic dust, but may be due to exposure to poisonous gases emitted from the flour mill9.

Based on different related study, researcher shows that sex, age, education level, long work experience in dusty working environments, smoking habit, exposure to dust and previously identified chronic respiratory symptoms increases the risks of developing chronic respiratory symptoms. While higher education, effective dust control measures and training on occupational health and safety related to respiratory health problems were important determinant factors for maintaining the respiratory health of workers engaged in dusty ${ }^{10}$.

Thus, occupational respiratory problem is one of the most important causes for the mortality and morbidity among occupational workers. Moreover, associated factors are responsible for the occurrence of respiratory symptoms among industrial workers.

\section{OBJECTIVES}

- To estimate the prevalence of respiratory problems among industrial workers.

- To explore associated factors with respiratory problems.

\section{METHODS}

A cross sectional descriptive method was used to determine the prevalence and associated factors with respiratory problems among 150 industry workers of Pokhara Industrial Estate in Kaski district. It was established on 2 October 1974 AD (16 ${ }^{\text {th }}$ Ashwin, 2031 BS). Non probability purposive technique was used to select flour industry. Non probability consecutive sampling technique was used to select sample. Semi-structured interview schedule was used. The interview schedule was divided into three parts:

Part I: Socio demographic performa

Part II: Prevalence of respiratory problems

Part III: Questions related to associated factors with respiratory problems

Validity of the instrument was established by developing the instruments on the basis of literature review, opinion of subject experts and research advisors. Reliability of the instrument was calculated by using Karl Pearson's correlation coefficient test by adopting Split Half technique. Pre-testing of instrument was conducted among $10 \%$ of the total sample size.

Data was collected after getting approval from Pokhara University, obtained written official permission from the head of industry; for Shree Gauri Shankar Foods Pvt. Ltd, Shree Fewa Pauroti Pvt. Ltd., Shree Taja Pauroti Pvt. Ltd., and Shree Himshree Food Pvt. Ltd. to give their permission for data collection. Privacy and confidentiality was maintained.

Ethical clearance was taken from Institutional Review Committee board of Pokhara University. The researcher obtained written official permission from the authority of industry.

After collection of data, editing was done manually on the same day of data collection. The collected data was coded and entered in SPSS 16. 


\section{RESULTS}

\section{Organization and presentation of related data}

Section I: Socio-demographic characteristics of respondents

Table 1: Socio-demographic characteristics of respondents $(\mathrm{n}=150)$

\begin{tabular}{|c|c|c|}
\hline Variables & Frequency (f) & Percent (\%) \\
\hline \multicolumn{3}{|l|}{ Age ( in years) } \\
\hline $20-29$ & 57 & 38.00 \\
\hline $30-39$ & 48 & 32.00 \\
\hline $40-49$ & 37 & 24.70 \\
\hline $50-59$ & 08 & 5.30 \\
\hline \multicolumn{3}{|l|}{ Sex } \\
\hline Males & 66 & 44.00 \\
\hline Females & 84 & 56.00 \\
\hline \multicolumn{3}{|l|}{ Religion } \\
\hline Hindu & 135 & 90.00 \\
\hline Buddhists & 05 & 3.30 \\
\hline Christians & 09 & 6.00 \\
\hline Muslim & 01 & 7.00 \\
\hline \multicolumn{3}{|l|}{ Ethnicity } \\
\hline Dalit & 06 & 4.00 \\
\hline Disadvantages non dalit terai people & 16 & 10.70 \\
\hline Religious minorities & 29 & 19.30 \\
\hline Relatively disadvantaged janajati & 32 & 21.30 \\
\hline Relatively advantaged janajati & 19 & 12.70 \\
\hline Upper caste group & 48 & 32.00 \\
\hline \multicolumn{3}{|l|}{ Types of family } \\
\hline Nuclear & 70 & 46.70 \\
\hline Joint & 78 & 52.00 \\
\hline Extended & 02 & 1.30 \\
\hline \multicolumn{3}{|l|}{ Place of residence (Temporary) } \\
\hline Urban & 150 & 100.0 \\
\hline Rural & 00 & 0.00 \\
\hline \multicolumn{3}{|l|}{ Educational status } \\
\hline Illiterate & 04 & 2.70 \\
\hline Informal education & 23 & 15.30 \\
\hline Primary & 39 & 26.00 \\
\hline Secondary & 69 & 26.00 \\
\hline Higher secondary & 13 & 8.70 \\
\hline Bachelor and above & 02 & 1.30 \\
\hline \multicolumn{3}{|l|}{ Income per month (Rs.) } \\
\hline Less than 5,000 & 03 & 2.00 \\
\hline $5,001-10,000$ & 46 & 30.70 \\
\hline $10,001-15,000$ & 100 & 66.70 \\
\hline More than 15,000 & 01 & 7.00 \\
\hline \multicolumn{3}{|c|}{ Information about work-related problems } \\
\hline Yes & 94 & 62.70 \\
\hline No & 56 & 37.30 \\
\hline \multicolumn{3}{|l|}{ Sources of information ( $n=94)$} \\
\hline Different medias & 05 & 5.30 \\
\hline Health personnel & 05 & 5.30 \\
\hline Family members/ Friends & 16 & 17.0 \\
\hline Work place & 68 & 72.3 \\
\hline
\end{tabular}

The data shows that out of 150 respondents, most 57 (38\%) of the respondents were within 20 - 29 years majority were 84 (56.0\%) females. Majority 135 (90\%) of respondents were Hindus. Maximum 48 (32.0\%) were from upper caste group. Likewise, there were maximum 78 (52.0\%) respondents having joint family.

With regards to their temporary residence, $100 \%$ were from urban area. In terms of their educational status, majority 69 (46.0\%) had secondary level education. In terms of income per months, 100 (66.7\%) respondents earned Rs 10.001 - 15,000.

Most 94 (62.7\%) of the respondents knew about the work related respiratory problems and in terms of source of information about work-related respiratory problems, majority $68(72.3 \%)$ said their work place where as rest of them $16(17.0 \%), 5(5.3 \%)$ and $5(5.3 \%)$ said family members/friends.

\section{Section II: Distribution of respondents according to the presence of respiratory problems within 6 months}

The data represents more than half 103 (68.70\%) of the respondents had work-related respiratory problems and $100(66.67 \%)$ respondents had only cough. Among 100, $79(79.0 \%), 16(16.0 \%)$ and five $(5.0 \%)$ respondents suffered from cough for less than seven days, more than seven days and equal to seven days respectively. Among 150 respondents, $58(38.67 \%)$ respondents had presence of only phlegm. Among them 43 (74.1\%), 14 (24.1\%) and $1(1.7 \%)$ respondents had clear color, yellow color, and red color of phlegm respectively. Also, among 103 respondents, there was presence of breathlessness, chest tightness and whistling problems among 65 (43.33\%), nine $(6.0 \%)$ and four $(2.67 \%)$ respondents.

\section{Section III: Distribution of respondents according to biological factors}

Total four $(2.7 \%)$ had respiratory problems among their family members. Among four respondents, there were presence of respiratory problems only in three (75\%) siblings and two (50\%) grand parents. Asthma was present only in two (50\%) and pneumonia only in two (50\%). 


\section{Distribution of respondents according to their personnel habits}

Total 15 (10\%) respondents had personal habits of smoking. Among 15 respondents, majority eight (53.3\%) respondents used one to five cigarettes per day where as rest three $(20 \%)$ respondents used less than one cigarette per day. With regards to the type of fuel used, maximum 145 (96.7\%) respondents used LPG gas.

\section{Distribution of respondents according to exposure related factor}

Majority 48 (32.0\%) were working for two to five years, 47 (31.3\%) were working for above 10 years, 28 (18.7\%) were working for six to ten years and 27 (18.0\%) were working for up to one year. With regards to work per day, majority 142 (94.2\%) of respondents working for more than eight hours whereas six (4.0\%) respondents worked for equal to eight hours and two (1.3\%) respondents worked for less than eight hours.

With regards to the most common exacerbating factors of their respiratory problems, most 63 (42.0\%) of the respondents said prolonged working hours. With regards to the most common alleviating factors of their respiratory problems, most 52 (34.70\%) of the respondents said that rest. With regards to the most common ways of managing their respiratory problems, most 83 (55.3\%) respondents said health check ups.

\section{Distribution of respondents according to occupational safety}

Data shows that with regards to occupational safety, most $88(58.7 \%)$ of respondents said there is facility of health checkup when it required and majority 135 (90\%) said that there is insurance facility.

\section{Distribution of respondents according to physical environment of industry}

Data shows that with regard to the physical environment, $100 \%$ respondents gave their positive response towards available of adequate space, ventilation and light.

Majority 101 (67.3\%) respondents said most common technique of waste management is Municipality tipper whereas 38 (25.3\%) said burning, seven (4.7\%) said decomposition and four $(2.7 \%)$ said dumping.

\section{Section IV}

Table 2: Association between demographic factors and respiratory problems $(\mathrm{n}=150)$

\begin{tabular}{|c|c|c|c|c|c|}
\hline \multirow{2}{*}{ Variables } & \multicolumn{2}{|c|}{ Respiratory problems } & \multirow{2}{*}{$x^{2}$} & \multirow{2}{*}{$p$-value } & \multirow{2}{*}{ DF } \\
\hline & Yes & No & & & \\
\hline \multicolumn{6}{|l|}{ Age (Years) } \\
\hline $20-29$ & $41(71.9 \%)$ & $16(28.1 \%)$ & \multirow{4}{*}{2.221} & \multirow{4}{*}{$0.528 \mathrm{NS}$} & \multirow{4}{*}{3} \\
\hline $30-39$ & $31(64.6 \%)$ & $17(35.4 \%)$ & & & \\
\hline $40-49$ & $24(64.9 \%)$ & $13(35.1 \%)$ & & & \\
\hline $50-59$ & $7(87.5 \%)$ & $1(12.5 \%)$ & & & \\
\hline \multicolumn{6}{|l|}{ Sex } \\
\hline Male & $42(63.6 \%)$ & $24(36.4 \%)$ & \multirow[t]{2}{*}{1.386} & \multirow[t]{2}{*}{$0.239 \mathrm{NS}$} & \multirow[t]{2}{*}{1} \\
\hline Female & $61(72.6 \%)$ & $23(27.4 \%)$ & & & \\
\hline \multicolumn{6}{|l|}{ Religion } \\
\hline Hindu & $89(65.9 \%)$ & $46(34.1 \%)$ & \multirow[t]{2}{*}{5.963} & \multirow[t]{2}{*}{$0.015 \#$} & \multirow[t]{2}{*}{1} \\
\hline Others & $14(93.3 \%)$ & $1(6.7 \%)$ & & & \\
\hline \multicolumn{6}{|l|}{ Ethnicity } \\
\hline Others & $71(69.6 \%)$ & $31(30.4 \%)$ & \multirow[t]{2}{*}{0.131} & \multirow[t]{2}{*}{$0.717 \mathrm{NS}$} & \multirow[t]{2}{*}{1} \\
\hline Upper caste group & $32(66.7 \%)$ & $16(33.3 \%)$ & & & \\
\hline \multicolumn{6}{|l|}{ Types of family } \\
\hline Nuclear & $50(71.4 \%)$ & $20(28.6 \%)$ & \multirow{2}{*}{0.465} & \multirow{2}{*}{$0.495 \mathrm{NS}$} & \multirow{2}{*}{1} \\
\hline Joint and extended & $53(66.2 \%)$ & $27(33.8 \%)$ & & & \\
\hline \multicolumn{6}{|l|}{ Educational status } \\
\hline Illiterate & $2(50.0 \%)$ & $2(50.0 \%)$ & \multirow{2}{*}{0.666} & \multirow{2}{*}{$0.415 \mathrm{NS}$} & \multirow{2}{*}{1} \\
\hline Others & $101(69.2 \%)$ & $45(30.8 \%)$ & & & \\
\hline \multicolumn{6}{|l|}{ Income per month (Rs.) } \\
\hline Less than and equal to & $28(57.1 \%)$ & $21(42.9 \%)$ & \multirow{3}{*}{4.492} & & \\
\hline 10,000 & & & & $0.034 \#$ & 1 \\
\hline More than 10,000 & $75(74.3 \%)$ & $26(25.7 \%)$ & & & \\
\hline Information about & & & & & \\
\hline work-related problems & & & & & \\
\hline Yes & $82(87.2 \%)$ & $12(12.8 \%)$ & 4344 & ○ी००\# & 1 \\
\hline No & $21(37.5 \%)$ & $35(62.5 \%)$ & 4.047 & $0.000 \pi$ & 1 \\
\hline
\end{tabular}

\# = significant, NS: Non significant, $\chi^{2}$ value at $1 \mathrm{df}$ is 3.84 , $p$ value is considered significant

Table 2 shows there is association of respiratory problems only with religion ( $\mathrm{p}$ value $=0.015$ ), income per months of respondents $(p$ value $=0.034)$ and the information they had about work-related respiratory problem ( $\mathrm{p}$ value $=$ 0.000). 


\section{Section V}

Table 3: Association between respiratory problems with the associated factors $(n=150)$

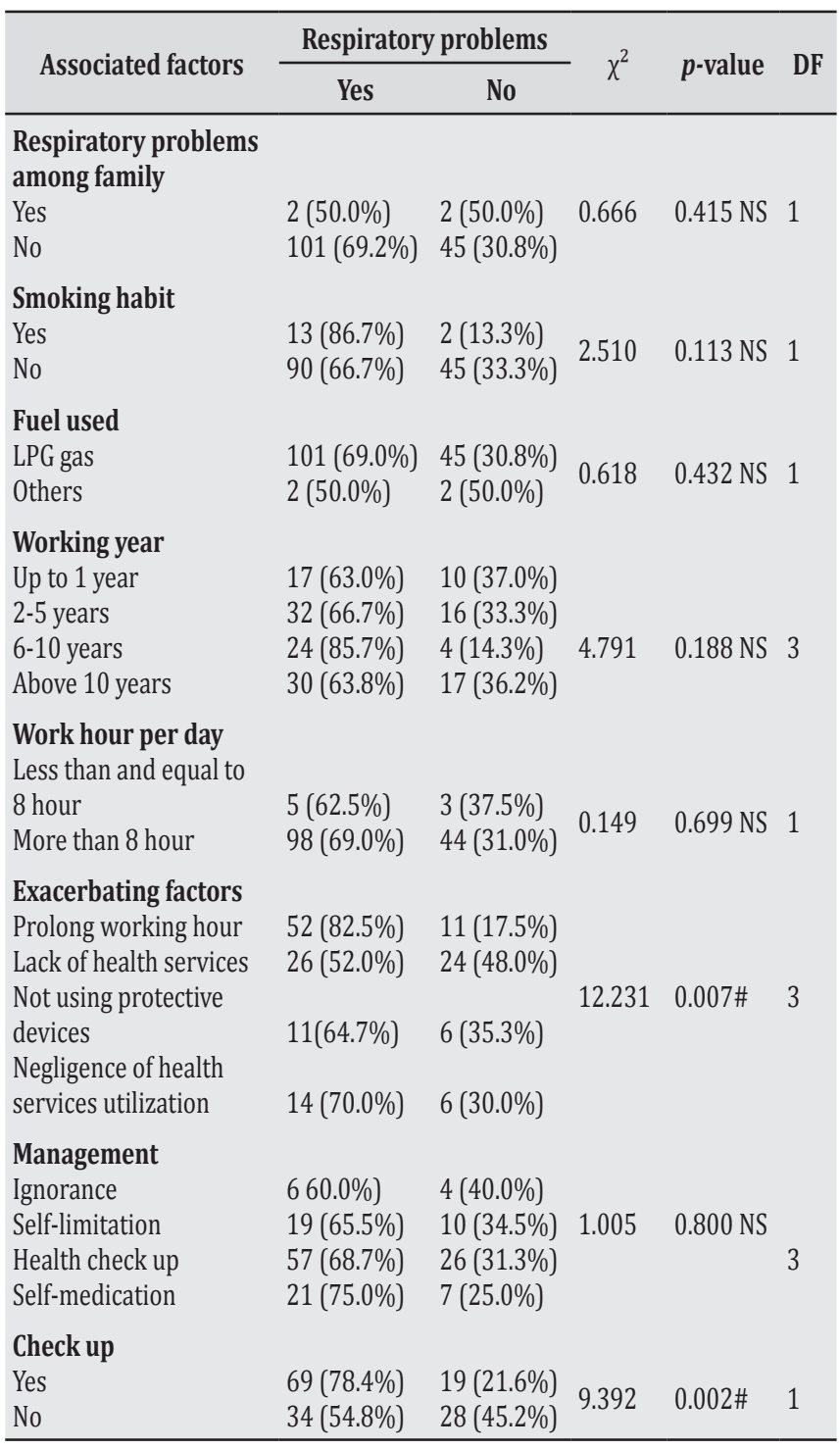

\# = significant, NS: Non significant, $\chi^{2}$ value at $1 \mathrm{df}$ is 3.84 , $p$-value is considered significant

The Table 3 shows there is association of respiratory problems only with exacerbating factors ( $\mathrm{p}$ value $=$ 0.007 ) and available of health check up facility in their industry ( $\mathrm{p}$ value $=0.002$ )

\section{DISCUSSION}

\section{Prevalence of respiratory problems}

Similar study was conducted among wheat flour mill workers in Ibadan, Nigeria among 30 internal controls and 121 external controls revealed that $54 \%$ of the flourmillers reported at least one respiratory symptom ${ }^{11}$.Study conducted among 200 exposed and 200 non-exposed groups of flour mill workers in Southern Egypt revealed $87.5 \%$ productive cough, $60 \%$ dyspnea and $7 \%$ chest pain among exposed group which is somewhat similar to our study $^{12}$.

\section{Associated factors of respiratory problems}

A similar study was conducted among 229 participants to determine the prevalence and factors associated with sensitization to wheat flour and $\alpha$-amylase in bakers in Douala, Cameroon, Central Africa shows that most of respondents (54.6\%) were working for more than 8 hours per day and majority (71.9\%) were not smokers ${ }^{13}$.

\section{Association of respiratory problems with demographic variables and its associated factors}

A cross-sectional study was conducted among 79 cases and 73 controls in Tanzanian primary coffee-processing factories, Kilimanjaro shows the differences between prevalence between exposed and unexposed groups were not statistically significant but it was found to be higher among exposed groups which recommended that interventions for reduction of dust levels and provision of respiratory protective equipment are necessary ${ }^{14}$.

\section{CONCLUSIONS}

The result of the study showed that most 103 (68.70\%) of the respondents had work-related respiratory problems. the prevalence of cough, phlegm, breathlessness, chest tightness and whistling problems were 100 (66.67\%), 58 (38.67\%), 65 (43.33\%), 9 (6.0\%) and 4 (2.67\%). Among different demographic variables, association of respiratory problems was found with religion ( $p$ value $=0.015$ ), income per months of respondents and the information they had about work-related respiratory problem. The result shows there is association of respiratory problems only with exacerbating factors and available of health checkup facility in their industry.

\section{Acknowledgements}

This research report has been completed with the support, guidance and co-operation from many people. I would like to express my sincere gratitude, who is an asset and I am privileged to have opportunity to express to Pokhara University, School of Health and Allied Science for providing an opportunity to conduct this study.

I heartily express my gratitude to Mr. Himalayan Bhandari, Administrator of Pokhara Industrial Estate for his help and cooperation. Also, the entire members of Shree Gauri Shankar Foods Pvt. Ltd., Shree Himshree Foods Pvt. Ltd., 
Shree Fhewa Pauroti Pvt. Ltd., and Shree Taja Pauroti Pvt. Ltd. of Pokhara Industrial Estate including all the respondents without whose co-operation this study would not be achievable.

\section{REFERENCES}

1. Joshi SK. Awakening to the occupational health problems. Kathmandu University medical journal (KUMJ). 2005 Jul 25; 3(11): 206-7. [cited on : 2016/06/20]. Available from: http://member.wnso. org/drsunilkj/OHEditorial.htm

2. S. Jitendra.Population Composition in Nepal by Occupation. [cited on:2016/06/22]. Available from: http://www.imnepal.com/population-nepal-nepalitour-places/

3. Food Processing. [cited on:2016/06/28]. Available from:www.clarcorindustrialair.com/industries / foodprocessing

4. World Health Organization. Implementation of the WHO strategy for prevention and control of chronic respiratory diseases: Meeting report, 11-12 February 2002. [cited on:2016/06/28]. Available from: http:// www.searo.who.int/nepal/mediacentre/2002_ implementation_of_who_strategy_for_prevention_ and_control_of_crd.pdf?ua=1

5. Rafiee-Pour A, Rafiee-Pour E, Asghari M, Zadeh NG, Dehghan SF. Respiratory effects of exposure to flour dust: A case study among workers of flour production factories in Arak. Journal of Paramedical Sciences. 2015 Aug 26; 6(3). [cited on:2016/06/22], Available from:http://journals.sbmu.ac.ir/jps/article/ download/9823/7496.

6. Occupational respiratory diseases in Australia. Safety A, Council C.ASCC, April. 2006. [cited on: 2016/06/17], Available from: http://www.safeworkaustralia. gov.au / sites / SWA / a bout / Publications / Documents/413/OccupationalrespiratoryDiseases_ Australia_2006_ArchivePDF.pdf

7. Global Estimates of occupational accidents and workrelated illnesses. Tampere University of Technology. 2014, [cited on: 2016/06/17]. Available from: https:// www.wshinstitute.sg/files/wshi/upload/cms/file/ Global\%20Estimates\%20of\%200ccupational\%20 Accidents $\% 20$ and $\% 20$ Work-related $\% 20$ Illness $\% 20$ 2014.pdf

8. WHO Global Plan of Action on Workers' Health (2008-
2017), Global country survey 2008 - 2009, Geneva, 2013. [cited on:2016/06/17]. Available from: http:// www.who.int/entity/occupational_health/who_ workers_health_web.pdf

9. Urom SE, Osim EE, Antai AB, Aribo EO. Prevalence of respiratory and non-respiratory symptoms among workers chronically exposed to wheat flour dust and other possible occupational hazard in flour mill industry, Calabar, Nigeria. IOSR Journal of Dental and Medical Sciences (IOSR-JDMS). 1(14):36-9. [Cited on: 2016/06/22]. Available from: http://www. iosrjournals.org/iosr-jdms/papers/Vol14-issue7 / Version-8/I014783639.pdf

10. Gizaw Z, Yifred B, Tadesse T. Chronic respiratory symptoms and associated factors among cement factory workers in Dejen town, Amhara regional state, Ethiopia, 2015. Multidisciplinary Respiratory Medicine. 2016 Mar 1; 11(1): 1. [cited on: 2016/06/13]. Available from: http://www.ncbi.nlm.nih.gov/pmc/ articles/PMC4772492/pdf/40248_2016_Article_43. pdf

11. Ijadunola KT, Erhabor GE, Onayade AA, Ijadunola MY, Fatusi AO, Asuzu MC. Prevalence of respiratory symptoms among wheat flour mill workers in Ibadan, Nigeria. American Journal of Industrial Medicine. 2004 Mar 1; 45(3): 251-9. [Cited on: 2016/06/18]. Available from: http://www.ncbi.nlm.nih.gov/ pubmed/14991852

12. Mohammadien HA, Hussein MT, El-Sokkary RT. Effects of exposure to flour dust on respiratory symptoms and pulmonary function of mill workers. Egyptian Journal of Chest Diseases and Tuberculosis. 2013 Oct 31; 62(4): 745-53. [Cited on: 2016/06/18]. Available from: http://dx.doi.org/10.1016/j.ejcdt.2013.09.007

13. Ngahane BHM, NdeF, Ngomo E, Afane E. Sensitization to workplace respiratory allergens among bakery workers in Douala, Cameroon: A cross-sectional study. Biomed Central Journal. 2015 Apr 10; 10 (13): 1-6. [Cited on: 2016/06/27]. Available from: http:// download.springer.com/static/pdf/667/art\%253A1 0.1186\%252Fs13223-015-0080-2.pdf

14. Sakwari G,Bråtveit M, Mamuya S.HD and, Moen B.E. Dust exposure and chronic respiratory symptoms among coffee curing workers in Kilimanjaro: A cross sectional study. Biomed Central Pulmonary Medicine. 2011; 11: 54; 1-8. [Cited on: 2016/06/24]. Available from: https://www.ncbi.nlm.nih.gov/pmc/articles/ PMC3247191/pdf/1471-2466-11-54.pdf 